\title{
Perdagangan Luar Negeri Kakatua Koki (Cacatua galerita Latham, 1790) Dan Usaha Penangkarannya Di Fasilitas Penangkaran Pusat Penelitian Biologi-LIPI (Export of Sulphur-Crested Cockatoo (Cacatua galerita Latham, 1790) and that Captive Breeding at Research Center of Biology Breeding Facility-LIPI)
}

\author{
Rini Rachmatika, Suparno, Siti Nuramaliati Prijono, Herjuno Ari, Andri Permata Sari, \& \\ Sinta Maharani
}

Pusat Penelitian Biologi-LIPI, Gedung Widyasatwaloka Jln. Raya Jakarta-Bogor Km. 46 Cibinong Science Center, Cibinong 16911, Telp/Fax 021-8765056. Email: r.rachmatika@gmail.com

\author{
Memasukkan: Agustus 2019, Diterima: Maret 2020
}

\begin{abstract}
Psittacine, for instance, sulphur-crested cockatoo (C. galerita) was widely traded, domestically and internationally due to its beautiful plumages and well-known smartness. It is essential to know the trading rate of the bird. The information can use both to control the trade and prevent over-harvesting from the wild. Captive breeding is one of few attempts performed to reduce wildlife over-harvesting. This research aimed to study the international trading rate of $C$. galerita and to review captive breeding management in our facility. The export data during 1981-2018 collected from CITES websites' database. Based on the obtained data, export activities were as follow: 7884 birds exported as reported by the importer. Meanwhile, 12.798 birds were reported by the exporter, and the birds exported to 39 countries. The birds exported using code $\mathrm{C}$ (bred in captivity), W (wild), F (born in captivity), U (unknown) dan I (confiscated or seized). Captive breeding performed as ex-situ conservation attempts to reduce wild harvesting. Captive Breeding attempts in Research Center for Biology LIPI successfully bred this species using three pairs of broodstocks. The obtained captive breeding data were as follow reproductive frequency 1-2 times/year with 1-2 eggs/clutch. The incubation period \pm 28 days. Egg weight is $19 \pm 1.12 \mathrm{~g}$. Egg length $4.28 \pm 0.08 \mathrm{~mm}$ and egg width $3.35 \pm 0.05 \mathrm{~mm}$. Weight of chicks seven days of age is $95 \pm 2.34$ grams. The chick comes out of the nest at \pm 11 weeks and fledgeling age at \pm 13 weeks. Feed consist of grains, fruits, vegetables, pellets, coconuts and bird cakes. Our captive breeding indeed was far from perfect. Implementation of recent technology still needs to be done to enhance our captive breeding management.
\end{abstract}

Keywords: cockatoo, exsitu conservation, captive breeding, trade

\begin{abstract}
ABSTRAK
Burung paruh bengkok merupakan burung yang banyak diperjualbelikan di dalam negeri maupun luar negeri karena memiliki bulu yang indah dan dikenal sebagai burung yang pandai. Pentingnya mengetahui tingkat perdagangan dari jenis ini adalah untuk tetap mengontrol perdagangan jenis ini dan usaha antisipasinya, salah satunya berupa penangkaran. Data perdagangan luar negeri jenis Kakatua Koki (Cacatua galerita) dari tahun 1981-2018 didapat melalui situs CITES trade database. Berdasarkan data tersebut tercatat 7884 ekor (dilaporkan oleh importir) atau 12.798 ekor (dilaporkan oleh eksportir) C. galerita yang diekspor ke 39 negara tujuan. Burung tersebut diekspor dengan kode $\mathrm{C}$ (Bred in captivity), W (Wild), F (Born in captivity), U (Unknown) dan I (Confiscated or seized). Usaha penangkaran pun kerap dilakukan untuk mendukung konservasi jenis tersebut agar tetap dapat dimanfaatkan, namun tidak mengambil langsung dari alam. Penangkaran $C$. galerita di Pusat Penelitian Biologi-LIPI berhasil mengembangbiakkan jenis ini dengan 3 pasang indukan produktif. Frekuensi reproduksi 1-2 kali/tahun dengan jumlah 1-2 telur/peneluran. Masa pengeraman berkisar \pm 28 hari. Berat telur sekitar $19 \pm 1,12$ g. Panjang telur mencapai 4,28 $\pm 0,08 \mathrm{~mm}$ dan lebar telur mencapai 3,35 $\pm 0,05 \mathrm{~mm}$. Anakan dengan umur 7 hari memiliki berat 95 $\pm 2,34$ gram. Anakan keluar sarang pada umur \pm 11 minggu dan dapat terbang pada umur \pm 13 minggu. Pakannya berupa biji-bijian, buah, sayur, pelet, kelapa dan kue burung.
\end{abstract}

Kata Kunci: kakatua, konservasi eksitu, penangkaran, perdagangan

PENDAHULUAN

Burung paruh bengkok (Ordo Psittaciformes) terdiri dari 4 famili yaitu Strigopidae, Cacatuidae,
Psittacidae, dan Psittaculidae (Gill \& Donsker 2018). Burung ini merupakan salah satu kelompok burung yang memiliki daya tarik yang tinggi, karena bulunya yang indah, tingkah laku yang 
menarik dan termasuk burung yang pintar. Indonesia memiliki 7 jenis burung kakatua dari 21 jenis yang ada di dunia (Gill \& Donsker 2018). Populasi burung kakatua di alam semakin menurun akibat dari semakin berkurangnya habitat dan semakin tingginya pemanfaatan oleh masyarakat melalui penangkapan burung kakatua dari alam untuk diperdagangkan. Namun, pemanfaatan tersebut harus memperhatikan pula kelestarian jenis tersebut di alam. Salah satu upaya agar pemanfaatan tetap berkelanjutan adalah dengan usaha penangkaran. Penangkaran dapat menjadi salah satu cara untuk mengurangi pengambilan dari alam.

Cacatua galerita yang memiliki nama lokal kakatua koki (Sukmantoro dkk. 2007) merupakan jenis yang banyak diperdagangkan baik di dalam maupun luar negeri. Burung ini merupakan jenis yang dilindungi dalam Peraturan Menteri Lingkungan Hidup dan Kehutanan Nomor P.92 Tahun 2018 tentang Perubahan atas Peraturan Menteri Lingkungan Hidup dan Kehutanan Nomor P.20 Tahun 2018 tentang jenis tumbuhan dan satwa yang dilindungi. Dalam IUCN jenis ini masuk dalam kategori Least Concern namun memiliki kecenderungan populasi yang menurun (IUCN 2019) dan CITES memasukkan jenis ini ke dalam Appendiks II (CITES 2017).

Cacatua galerita berukuran $45-55 \mathrm{~cm}$ dengan berat $815-975 \mathrm{~g}$. Tubuhnya memiliki bulu berwarna putih dengan warna bulu kuning pada bulu yang menutupi telinga, bulu sayap dan ekor bagian bawah berwarna kekuningan. Burung ini memiliki jambul berwarna kuning, paruh berwarna hitam, kaki abu-abu gelap dan kulit periopthalmic berwarna putih. Iris matanya berwarna cokelat gelap pada jantan dan cokelat kemerahan pada betina. Juvenil sama dengan dewasa tetapi iris matanya cokelat pucat. Pada burung yang sangat muda terdapat sedikit warna abu-abu pada mahkota (Forshaw \& Cooper 1989; Rowley et al. 2019).

Ekspor dari komoditas burung kakatua menghasilkan devisa bagi negara. Konsekuensi dari ekspor adalah harus adanya mekanisme kontrol dalam perdagangan satwa liar tersebut. Salah satu bentuk kontrol dari perdagangan luar negeri adalah dengan mengetahui fluktuasi volume dari tahun ke tahun. Kontrol tersebut bukan hanya dari segi jumlah, tetapi juga dari perolehan komoditas tersebut. Selain itu, mekanisme perlindungan suatu jenis pun harus ditetapkan agar jenis tersebut dapat dimanfaatkan, namun dengan mekanisme yang diatur oleh pemerintah. Karena itu, penting untuk mengetahui seberapa besar volume ekspor satwa liar khususnya kakatua koki dan juga bersumber dari mana. Hal tersebut sebagai antisipasi agar kelestarian jenis ini tetap terjaga. Jika diketahui sumber perdagangan berasal dari alam liar, dikhawatirkan suatu saat jenis ini mengalami kelangkaan. Jadi, untuk menghindari pemanenan dari alam, hasil dari penangkaran dapat sebagai alternatif sumber untuk pemanfaatan, baik untuk kebutuhan dalam negeri maupun luar negeri.

Dalam kurun waktu 2011-2015 ekspor burung dari Indonesia mengalami peningkatan, puncaknya pada 2013, kembali turun pada 2014 dan naik kembali pada 2015, dimana 95,7\% berasal dari penangkaran dan $99,7 \%$ dalam bentuk hidup. Jenis yang paling banyak diekspor pada kurun waktu tersebut adalah jenis $C$. galerita. (CITES Trade Data Dashboard 2019). Oleh karena itu, pentingnya mengetahui fluktuasi perdagangan luar negeri $C$. galerita serta menginformasikan bagaimana teknis penangkarannya. Tujuan dari adanya penangkaran agar pemanfaatan dari suatu jenis tidak bergantung pada panen dari alam liar. Selain itu, penangkaran diharapkan dapat meningkatkan survival rate anakan dan tingkat reproduksi dari suatu jenis. Penangkaran dapat pula melakukan pelepasliaran (restocking) suatu jenis yang hampir punah ke habitat aslinya.

\section{BAHAN DAN CARA KERJA}

Data perdagangan luar negeri jenis Cacatua galerita diperoleh dari situs CITES trade database yaitu sebuah portal sebagai sumber informasi mengenai semua jenis tumbuhan dan satwa liar yang dimanfaatkan dalam lingkup internasional. Informasi yang terdapat dalam situs ini adalah berdasarkan laporan dari negara pengekspor atau negara pengimpor dimana mereka sudah meratifikasi CITES. Informasi yang dapat diperoleh yaitu tahun, negara tujuan, negara pengekspor, sumber komoditas, tujuan ekspor, bagian yang 
dimanfaatkan, dan jenis yang dimanfaatkan. Informasi Seleksi data yang dilakukan adalah dengan memasukan periode (tahun) dari tahun 1980-2018, negara tujuan yaitu semua negara (all countries), negara pengirim yaitu Indonesia, sumber yaitu semua kode (all source), tujuan yaitu semua tujuan (all purpose), bagian yang diperdagangkan yaitu semua bentuk (all term) dan memasukkan nama jenis Cacatua galerita. Data yang diperoleh diolah secara deskriptif dengan menampilkan tabel dan grafik.

Upaya penangkaran burung jenis Cacatua galerita dilakukan di Penangkaran burung Bidang Zoologi, Pusat Penelitian Biologi-LIPI, Cibinong. Data penangkaran diperoleh dalam kurun waktu 2015-2018. Aspek yang diteliti adalah aspek nutrisi, reproduksi, dan perilaku. Jumlah burung jantan pada kurun waktu tersebut 6-7 ekor. Jumlah burung betina pada kurun waktu tersebut 7-8 ekor dengan rata-rata umur dewasa. Hanya beberapa yang dapat ditentukan umurnya secara pasti karena lahir di penangkaran. Jumlah pasangan produktif yaitu 3 pasang. Dari semua pasangan produktif, bukan individu yang menetas di penangkaran. Kandang yang digunakan sebanyak sembilan kandang. Tiga kandang berukuran lebih besar yaitu $400 \mathrm{~cm}$ x $340 \mathrm{~cm}$ x $290 \mathrm{~cm}$ dan enam kandang berukuran lebih kecil yaitu $200 \mathrm{~cm}$ x $340 \mathrm{~cm}$ x $290 \mathrm{~cm}$.

Kandungan nutrisi pakan dianalisis di Laboratorium Nutrisi, Pusat Penelitian BiologiLIPI. Alat pendukung yang digunakan untuk menimbang anakan dan telur, mengukur suhu dan kelembaban, mengukur telur dan mengukur kandang serta sarang yaitu timbangan digital, termohigrometer, jangka sorong, dan meteran. Analisa data menggunakan metode deskriptif.

\section{HASIL}

\section{Perdagangan}

Indonesia meratifikasi CITES sejak dikeluarkannya Keputusan Presiden No. 43 Tahun 1978 tentang Convention On International Trade in Endangered Species of Wild Fauna and Flora yang berarti bahwa setiap komoditas tumbuhan dan satwa liar yang diperdagangkan dari dan ke luar negeri wajib mengikuti aturan yang telah ditetapkan oleh konvensi tersebut, termasuk salah satunya jenis Cacatua galerita. Jenis $C$. galerita mulai diekspor pada tahun 1981 dan data terakhir yang tercatat yaitu pada tahun 2018. Gambar 1 memperlihatkan fluktuasi dari ekspor C. galerita dari tahun 1981-2018.

Dalam dokumen ekspor, negara pengirim wajib mencantumkan negara tujuan. Negara tujuan ekspor jenis $C$. galerita, yaitu sebanyak 39 negara tujuan dapat dilihat pada Tabel 1.

Selain negara tujuan, maka pengekspor juga wajib mencantumkan bentuk komoditas yang akan diekspor dalam bentuk apa. Pada $C$. galerita terdapat empat bentuk komoditas yang diekspor, yaitu tubuh (bodies), bulu (feathers), hidup (live) dan spesimen (specimen). Dalam hal kelengkapan informasi harus dicantumkan tujuan komoditas satwa liar tersebut diekspor, apakah untuk breeding, personal, sirkus, penelitian, atau komersial.

Informasi penting lainnya adalah berasala dari manakah satwa liar tersebut, apakah dari penangkaran, sitaan, atau dari alam. Hal tersebut sangat penting sebagai informasi sustainability dari suatu jenis yang diperdagangkan.

\section{Penangkaran}

Jenis kakatua yang ditangkarkan di Penangkaran Burung, Pusat Penelitian Biologi, Bidang Zoologi-LIPI adalah Kakatua Koki yang memiliki nama ilmiah Cacatua galerita triton yang terdistribusi di Papua, Papua Nugini, dan pulau di sekitarnya (Rowley et al. 2019). Terdapat dua ukuran kandang kakatua di Fasilitas Penangkaran burung Pusat Penelitian Biologi-LIPI. Kandang besar berukuran $400 \mathrm{~cm} \mathrm{x}$ $340 \mathrm{~cm}$ x $290 \mathrm{~cm}$, sedangkan kandang yang lebih kecil berukuran $200 \mathrm{~cm} \times 340 \mathrm{~cm} \times 290 \mathrm{~cm}$. Ukuran kedua kandang tersebut sudah terbukti dapat digunakan untuk perkembangbiakan $C$.

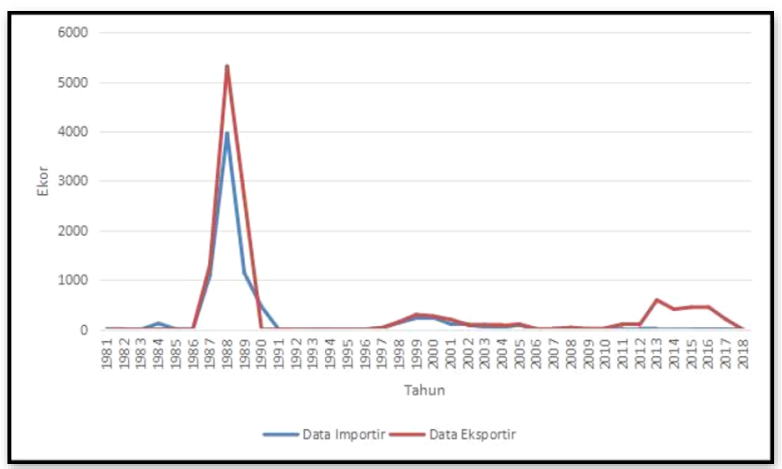

Gambar 1. Grafik perdagangan luar negeri Cacatua galerita selama sejak 1981-2018 
Tabel 1. Negara tujuan ekspor Cacatua galerita pada rentang waktu 1981-2018 (CITES 2019)

\begin{tabular}{|c|c|c|}
\hline Negara & $\begin{array}{c}\text { Jumlah yang } \\
\text { dilaporkan } \\
\text { importir (ekor) }\end{array}$ & $\begin{array}{c}\text { Jumlah yang } \\
\text { dilaporkan } \\
\text { eksportir (ekor) }\end{array}$ \\
\hline Uni Emirat Arab & 0 & 30 \\
\hline Armenia & 0 & 24 \\
\hline Austria & 21 & 21 \\
\hline Bangladesh & 0 & 408 \\
\hline Belgium & 0 & 10 \\
\hline Bahrain & 0 & 47 \\
\hline Switzerland & 0 & 18 \\
\hline Czech Republic & 66 & 69 \\
\hline Jerman & 41 & 92 \\
\hline Spanyol & 592 & 664 \\
\hline Perancis & 149 & 229 \\
\hline Inggris & 4 & 163 \\
\hline Indonesia & 0 & 1 \\
\hline Italia & 134 & 59 \\
\hline Yordania & 0 & 408 \\
\hline Jepang & 70 & 99 \\
\hline Kuwait & 0 & 60 \\
\hline Srilanka & 20 & 0 \\
\hline Libya & 0 & 40 \\
\hline Meksiko & 137 & 149 \\
\hline Malaysia & 115 & 54 \\
\hline Mozambik & 0 & 62 \\
\hline Belanda & 0 & 2 \\
\hline Nepal & 0 & 109 \\
\hline Oman & 0 & 182 \\
\hline Panama & 1 & 0 \\
\hline Pakistan & 0 & 975 \\
\hline Qatar & 0 & 29 \\
\hline Rusia & 0 & 30 \\
\hline Arab Saudi & 19 & 3 \\
\hline Swedia & 1 & 0 \\
\hline Singapore & 0 & 1787 \\
\hline Slovakia & 0 & 12 \\
\hline Turki & 0 & 94 \\
\hline Taiwan & 0 & 3 \\
\hline Ukraina & 0 & 13 \\
\hline Amerika Serikat & 6484 & 7028 \\
\hline Vietnam & 0 & 1 \\
\hline Afrika Selatan & 30 & 26 \\
\hline
\end{tabular}

galerita di penangkaran.

Cincin atau ring yang digunakan untuk indukan berupa open ring yang terbuat dari bahan alumunium. Penangkaran komersial yang memanfaatkan hasil penangkarannya diharuskan untuk memakai cincin berupa close ring untuk anakan. Jika menggunakan close ring untuk anakan C. galerita maka ukuran diameter dalamnya sekitar $13 \mathrm{~mm}$ dan diameter luar $19 \mathrm{~mm}$ dengan material terbuat dari aluminium.

Salah satu faktor yang penting dalam keberhasilan sebuah penangkaran adalah pakan, Berikut adalah kandungan nutrien dari pakan kakatua koki (Tabel 5). Jenis pakan tidak harus semua diberikan, namun dalam setiap pemberian harus terdapat, sumber energi, sumber protein, dan sumber vitamin dan mineral.

C. galerita di fasilitas penangkaran burung Pusat Penelitian Biologi-LIPI memiliki frekuensi reproduksi 1-2 kali/tahun. Burung ini bertelur 1-2 butir/peneluran. Masa pengeraman \pm 28 hari. Berat telur $19 \pm 1,12$ g. Panjang telur $4,28 \pm 0,08 \mathrm{~mm}$ dan lebar telur 3,35 $\pm 0,05 \mathrm{~mm}$. Anakan umur 7 hari memiliki berat $95 \pm 2,34$ gram. Anakan keluar sarang pada umur \pm 11 minggu dan dapat terbang umur \pm 13 minggu. Proses bertelur jika lebih dari 1 butir tidak berlangsung pada waktu yang sama, begitupun dengan waktu penetasannya, biasanya berselang 1-2 hari.

Metode penetasan dan pemeliharaan anak yang diterapkan adalah penetasan telur dan pemeliharaan anak secara alami. Hal ini dikarenakan agar anakan yang dihasilkan dapat bersifat liar. Namun, untuk penangkaran komersial, dapat diterapkan metode penetasan dengan menggunakan inkubator dengan suhu $\pm 37 \mathrm{C}$. Metode pemeliharaan anak untuk penangkaran komersial dapat menggunakan metode pemeliharaan anak dengan cara handrearing. Metode penetesan dengan inkubator dan pemeliharaan anakan dengan handrearing dapat meningkatkan angka penetasan dan meningkatkan survival rate anakan. Kegagalan yang sering terjadi pada penetasan secara alami adalah telur dimakan predator atau terinjak oleh induk. Hal yang sering terjadi pada anakan pada pemeliharaan secara alami dengan induk adalah anakan sering mati terinjak oleh induk atau dimakan oleh predator.

\section{PEMBAHASAN}

\section{Perdagangan}

Convention on International Trade in Endangered Species of Wild Flora and Fauna (CITES) mengatur perdagangan satwa liar yang 
masuk ke dalam daftar appendiks agar mencegah dari kepunahan. CITES menyediakan sebuah sebuah situs untuk mengetahui volume perdagangan dari sebuah komoditas tumbuhan dan satwa liar (TSL), yaitu CITES trade database. Data tersebut dapat menjadi data untuk memonitor volume perdagangan TSL, khususnya dari dan yang masuk ke Indonesia. Cacatua galerita ditetapkan dalam daftar appendiks II sejak tahun 1981 (UNEP-WCMC, 2014). situs yang memuat data volume perdagangan satwa liar berdasarkan Gambar 1., volume ekspor jenis $C$. galerita yang paling tinggi yaitu pada tahun 1988, baik yang dilaporkan oleh importir (3.960 ekor) maupun yang dilaporkan oleh eksportir (5316 ekor). Menurut Haryoko (2018) C. galerita bukan merupakan jenis yang paling banyak volume ekspornya selama tahun 1981-2017, melainkan jenis Cacatua alba dimana volume perdagangannya tinggi pada kurun waktu 1981-1993, dan sampai tahun 2016 masih tercatat terdapat ekspor meskipun dalam jumlah yang tidak terlalu besar. Hal tersebut dikarenakan jenis $C$. alba adalah jenis yang belum dilindungi dalam Peraturan Pemerintah No. 7 Tahun 1999 tentang Pengawetan Jenis Tumbuhan dan Satwa. Kemudian C. alba baru masuk ke dalam jenis yang dilindungi bersama dengan $C$. galerita dan jenis paruh bengkok lainnya melalui Peraturan Menteri Lingkungan Hidup dan Kehutanan Republik Indonesia No. P.92/ MENLHK/SETJEN/KUM.1/8/2018 tentang Perubahan atas Peraturan Menteri Lingkungan Hidup dan Kehutanan No. P.20 /MENLHK/ SETJEN/KUM.1/6/2018 tentang Jenis Tumbuhan dan Satwa Yang Dilindungi. C. galerita pertama kali dilindungi dengan SK Mentan No.421/Kpts/ $\mathrm{Um} / 8 / 1970$ yang tertulis Cacatua galerita triton (Noerdjito \& Maryanto 2007)

Pada tahun 1991-2012, ekspor jenis ini sangat kecil. Salah satu penyebabnya karena pada tahun 1997 mulai ditemukan kasus flu burung di Hongkong yang telah mematikan banyak unggas dan menyebabkan 10 orang terinfeksi serta enam orang meninggal (WHO, 2004). Kasus flu burung di Indonesia pertama kali muncul tahun 2003 di Kabupaten Tangerang dan hingga 2007 telah menyebar ke 31 provinsi. Saat itu belum diketahui secara pasti bagaimana virus tersebut masuk ke
Indonesia (Fakultas Kedokteran Hewan UGM, 2006). Wabah flu burung saat itu sangat mempengaruhi perdagangan burung liar. Menurut McLeod et al. (2007), penyebaran flu burung sangat cepat melalui burung-burung liar.

Tabel 1. menunjukkan negara tujuan yang paling besar volume perdagangannya adalah ke Amerika Serikat, baik menurut laporan dari importir (6484 ekor) maupun laporan dari eksportir (7028 ekor). Amerika Serikat menjadi negara tujuan ekspor jenis ini sejak tahun 19822007, volume tertinggi yaitu pada tahun 1988 yaitu 3.879 ekor (menurut laporan importir) atau 4.199 ekor (menurut laporan eksportir). Menurut Thompsen et al. (1992), Eropa, Amerika Serikat dan Singapura adalah negara pengimpor burung dalam bentuk hidup yang paling banyak. Pada tahun 1989 dan 1990 terjadi penurunan yang cukup tajam pada ekspor C. galerita. Hal tersebut dikarenakan terjadi penolakan permintaan impor sebesar $40 \%$ pada komoditas burung paruh bengkok.

Komoditas tumbuhan dan satwa liar yang diekspor dikirim dalam berbagai bentuk, antara lain ada yang dalam bentuk hidup, spesimen, bagian tubuh, atau dalam bentuk mati. Di laporan perdagangan, bentuk spesimen yang diperdagangkan atau dikirim ini dinyatakan dalam kolom term (CITES 2013). Pada Tabel 2. terlihat bahwa sebagian besar ekspor $C$. galerita yaitu dalam bentuk hidup sekitar $99,8 \%$; sisanya dalam jumlah relatif sedikit yaitu dalam bentuk tubuh, bulu, dan bentuk spesimen.

Pada saat melaporkan perdagangan kepada sekretariat CITES pun wajib mencantumkan tujuan spesimen tersebut untuk dikirim. Terdapat beberapa tujuan spesimen yang diperdagangkan, antara lain B (Breeding in captivity or artificial propagation), E (Educational), G (Botanical garden), H (Hunting trophy), L (Law enforcement/ judicial/forensic), M (Medical (including biomedical research)), $\mathrm{N}$ (Reintroduction or introduction into the wild), $\mathrm{P}$ (Personal), Q (Circus or travelling exhibition), S (Scientific), $\mathrm{T}$ (Commercial) dan Z (Zoo) (CITES, 2013). Berdasarkan Tabel 3. dapat dilihat bahwa tujuan yang dilaporan oleh importir sebesar 98,78\% adalah untuk komersial. Sedangkan yang dilaporkan oleh eksportir sebagian besar yaitu $72,53 \%$ adalah blank yaitu tidak tercantum 
tujuan spesimen tersebut dikirim dan 27, 26\% untuk tujuan komersial

Source code yang disimbolkan dengan satu huruf menyatakan dari mana sumber spesimen yang diperdagangkan tersebut berasal sehingga dapat selalu termonitor bagaimana populasinya di alam (CITES 2013). Tabel 4. terlihat bahwa sebagian besar spesimen $C$. galerita yang dikirim tidak mencantumkan kode (source code) yaitu sebesar $82,53 \%$ (laporan importir) dan 72,53\% (laporan eksportir). Sedangkan $C$. galerita yang diekspor dan berasal dari penangkaran $(\mathrm{C})$ hanya sekitar $13,52 \%$ (laporan importir) dan 27,34\% (laporan eksportir)

\section{Penangkaran jenis Cacatua galerita}

Peran penting penangkaran yaitu untuk menyediakan data perilaku, fisiologis dan data lainnya yang sulit atau mahal jika dilakukan di habitat aslinya (Ricklefs \& Cadena 2007). Data tersebut berguna untuk pemodelan atau prediksi dan juga pengelolaan satwa liar terkait jenis-jenis tertentu. Menurut Peraturan Menteri Kehutanan Nomor P.19 Tahun 2005 tentang Penangkaran

Tabel 2. Jumlah Cacatua galerita yang diekspor berdasarkan laporan importir dan eksportir (\%)

\begin{tabular}{lcc}
\hline Bentuk & Importir & Eksportir \\
\hline Tubuh & 0,03 & 0 \\
Bulu & 0,14 & 0 \\
Hidup & 99,84 & 99,85 \\
Spesimen & 0 & 0,15 \\
\hline
\end{tabular}

Tabel 3. Tujuan Cacatua galerita yang diekspor berdasarkan laporan importir dan eksportir (\%)

\begin{tabular}{lcc}
\hline Bentuk & Importir ( \%) & Eksportir (\%) \\
\hline Tubuh & 0,03 & 0 \\
Bulu & 0,14 & 0 \\
Hidup & 99,84 & 99,85 \\
Spesimen & 0 & 0,15 \\
\hline
\end{tabular}

Tabel 4. Kode (source code) C. galerita yang diekpor selama tahun 1981-2017 (\%)berdasarkan laporan importir dan eksportir

\begin{tabular}{lcc}
\hline Kode & Importir & Eksportir \\
\hline Tanpa kode & 82,53 & 72,53 \\
C (Bred in captivity) & 13,52 & 27,34 \\
F (Born in captivity) & 0,03 & 0,1 \\
I (Confiscated or seized) & 0,01 & 0 \\
U (Unknown) & 3,75 & 0 \\
W (Wild) & 0,17 & 0,02 \\
\hline
\end{tabular}

Tumbuhan dan Satwa Liar, penangkaran adalah upaya perbanyakan melalui pengembangbiakan dan pembesaran tumbuhan dan satwa liar dengan tetap mempertahankan kemurnian jenisnya. Jadi hal pertama yang harus dipastikan adalah mengetahui dengan jelas jenis yang akan ditangkarkan. Jika jenis tersebut memiliki anak jenis maka harus dipastikan anak jenisnya. Selain itu perlu juga dipastikan jenis kelamin dari burung yang ditangkarkan. Jika burung tersebut sulit dibedakan jenis kelaminnya dari morfologi maka sebaiknya DNA sexing.

Kandang merupakan salah satu fasilitas penangkaran yang penting. Setiap jenis harus dipisahkan dari jenis lainnya. Kandang harus merupakan tempat yang nyaman dan disesuaikan dengan kebutuhan jenis tersebut. Jika memungkinkan agar memisahkan individu dengan umur yang berbeda, misalnya dewasa dan remaja (Lyons et al. 2017). Kandang bersifat permanen dimana dinding terbuat dari tembok dan jeruji besi. Di dalam kandang dilengkapi dengan sarang dari batang pohon palem yang kering, dengan diameter dalam minimal $60 \mathrm{~cm}$. Sarang bisa diletakkan secara horizontal di lantai maupun secara vertikal (di lantai maupun digantung). Kandang dilengkapi dengan tenggeran, tempat pakan dan minum.

Salah satu faktor yang sangat menentukan keberhasilan penangkaran adalah pakan. Pada Tabel 5. memperlihatkan beberapa jenis pakan beserta dengan kandungan nutriennya yang dapat diberikan pada burung kakatua koki di fasilitas penangkaran Pusat Penelitian BiologiLIPI. Selain pakan di atas, dapat juga diberikan pakan tambahan berupa pelet protein tinggi maupun pelet dengan rasa buah, cangkang cumi, juga diberikan kue burung. Sebagai pengayaan, terkadang diberikan kelapa dan jagung dalam bentuk utuh. Berdasarkan jenis pakan yang diberikan, biji bunga matahari, kacang tanah, dan telur ayam rebus dapat diberikan sebagai sumber protein, dan pemberiannya dapat dilakukan secara bergantian agar burung tidak bosan. Kecukupan protein akan berpengaruh terhadap pertumbuhan, pemeliharaan sel, homeostatis, fungsi kekebalan tubuh, dan reproduksi. (Lee et al. 2008). Pemberian pakan dilakukan pada pagi dan sore hari dengan jumlah pemberian pakan yang lebih banyak pada pagi hari dibandingkan sore hari. 
Jumlah rasio pakan harian, frekuensi dan waktu pemberian pakan merupakan bagian dari manajemen pakan yang mempengaruhi pertumbuhan dan konversi pakan (De Silva \& Anderson 1995; Goddard 1996)

Menurut Peraturan Menteri Kehutanan Nomor P.19 Tahun 2005 tentang Penangkaran Tumbuhan dan Satwa Liar, penandaan adalah pemberian tanda yang bersifat fisik pada bagian tertentu dari spesimen tumbuhan dan satwa liar atau bagian-bagiannya serta hasil daripadanya. Sedangkan menurut Keputusan Menteri Kehutanan Nomor 355/Kpts-II/2003 tentang Penandaan Spesimen Tumbuhan dan Satwa Liar, penandaan adalah pemberian tanda pada tumbuhan maupun satwa dalam rangka pemanfaatan tumbuhan dan satwa dengan tetap menjaga kelestariannya sebagai legalitas dengan menggunakan teknik tagging/banding, marking, transponder, pembuatan tato, label dan atau sertifikasi.

Penandaan yang digunakan untuk burung umumnya adalah tagging atau banding berupa ring/cincin. Namun, adapula yang menggunakan microchip sebagai penanda. Menurut Keputusan Menteri Kehutanan Nomor 355/Kpts-II/2003 tentang Penandaan Spesimen Tumbuhan dan Satwa Liar, tagging atau banding adalah pemberian tanda pada satwa di bagian tubuh tertentu dengan alat khusus seperti ear tag, wing band, close ring, dan leg band. Sedangkan transponder atau microchip adalah benda yang berisikan tanda atau kode digital yang dimasukkan ke dalam tubuh satwa.

Penjodohan dilakukan dengan meletakkan jantan dan betina di kandang yang bersebelahan, lalu dilihat interaksinya satu sama lain dalam kurun waktu 1-2 bulan. Jika terdapat perilaku yang cenderung untuk berdekatan, maka dilakukan penyatuan dalam satu kandang. Observasi perilaku tetap dilakukan untuk melihat interaksi keduanya. Pada satwa liar umumnya sangat selektif dalam pemilihan pasangan sehingga tidak mudah untuk memiliki pasangan yang berjodoh.

Pada Gambar 1. dan Gambar 2. ialah dua butir telur dan dua ekor anakan C. galerita di fasilitas penangkaran burung Pusat Penelitian Biologi-LIPI. Di fasilitas ini, burung tersebut memiliki frekuensi reproduksi 1-2 kali/tahun. Teknik pada saat berkembangbiak yaitu induk mengerami sendiri telurnya, lalu setelah menetas induk pun memelihara sendiri anakannya. Burung ini bertelur 1-2 butir/peneluran. Masa pengeraman \pm 28 hari. Berat telur $19 \pm 1,12$ g. Panjang telur 4,28 $\pm 0,08 \mathrm{~mm}$ dan lebar telur $3,35 \pm 0,05 \mathrm{~mm}$. Anakan umur 7 hari memiliki berat $95 \pm 2,34$ gram. Anakan keluar sarang pada umur \pm 11 minggu dan dapat terbang umur \pm 13 minggu. Beberapa hambatan yang berkaitan dengan reproduksi antara lain pecahnya telur pada saat pengeraman yang mungkin disebabkan karena terinjak oleh induk, matinya anakan pada umur

Tabel 5. Kandungan Bahan Kering dan Nutrien Pakan Penelitian

\begin{tabular}{lrrrrrrrr}
\hline Jenis Pakan & \multicolumn{1}{c}{ BK } & \multicolumn{1}{c}{ BO } & Abu & PK & \multicolumn{1}{c}{ LK } & SK & BET & \multicolumn{1}{c}{ EB } \\
& $(\%)$ & ---------------- & $(\mathbf{1 0 0 \%}$ BK) & --------- & kkal \\
\hline Jagung segar & 32,5 & 96,15 & 3,85 & 16,14 & 10 & 2,4 & 67,61 & 4522 \\
Kangkung & 14,1 & 88,3 & 11,7 & 33,63 & 0,44 & 1,1 & 53,13 & 4327 \\
Kelapa & 58,4 & 97,35 & 2,65 & 3,47 & 31,27 & 11,75 & 51,84 & 6340 \\
Pisang lampung & 27,43 & 86,05 & 4,21 & 3,5 & 0,46 & 2,28 & 89,55 & 3981 \\
Kacang tanah & 98,19 & 97,48 & 2,52 & 30,88 & 43,55 & 7,32 & 15,73 & 7802 \\
Wortel & 24,67 & 89,62 & 8,92 & 10,21 & 0,2 & 1,09 & 79,58 & 3094 \\
Kedondong & 12,35 & 95,71 & 4,29 & 3,99 & 0,56 & 17,93 & 73,23 & 4024 \\
Jambu biji & 33,2 & 99,45 & 0,55 & 0,82 & 0,2 & 2,29 & 96,15 & 4426 \\
Tauge & 12,05 & 94,48 & 5,52 & 3,91 & 0,41 & 19,6 & 70,57 & 4964 \\
Kacang panjang & 37,63 & 93,53 & 6,47 & 31,33 & 1,05 & 1,76 & 59,39 & 4476 \\
Biji bunga & 96,35 & 95,64 & 4,39 & 29,91 & 49,64 & 5,94 & 10,11 & 8313 \\
Telur ayam rebus & 31,13 & 96,38 & 3,62 & 54,79 & 31,71 & 0,75 & 9,13 & 6882 \\
\hline
\end{tabular}

BK = Bahan Kering; PK = Protein Kasar; SK = Serat Kasar; EB = Energi Bruto; BO = Bahan Organik; LK =Lemak Kasar; BETN = Bahan Ekstrak Tanpa Nitrogen

*)Laboratorium Pengujian Nutrisi Pusat Penelitian Biologi-LIPI 
di bawah 2 bulan, telur tidak menetas, telur yang dimangsa oleh predator seperti tikus dan kadal. Reproduksi pada C. galerita tidak jauh berbeda dengan kakatua lain seperti $C$. moluccensis, $C$. opthalmica, C. sulphurea citrinocristata dan $C$. haematuropygia dimana sekali bertelur 2-3 butir dengan masa pengeraman 28 hari dan anakan dapat terbang pada usia 11-15 minggu (O'Brien 2007)

Status kesehatan hewan yang baik akan mendukung kelangsungan hidup dan reproduksi pada satwa penangkaran. Manajemen kesehatan untuk penangkaran burung seperti kakatua memiliki tantangan tersendiri. Banyak jenis burung yang memiliki perilaku alami untuk menyembunyikan gejala sakit sehingga burung sebenarnya lebih sakit daripada gejala teramati (Hoppes 2018). Referensi fisiologi normal digunakan sebagai standar pemeriksaan fisik dan klinis pada kakatua. Referensi yang digunakan di penangkaran burung Pusat Penelitian BiologiLIPI tertera pada Tabel 6.

Pengobatan pencegahan yang dilakukan di fasilitas penangkaran burung Pusat Penelitian Biologi LIPI adalah desinfeksi kandang. Desinfeksi kandang dilakukan setiap setahun sekali di awal tahun. Desinfektan yang digunakan adalah Rodalon ${ }^{\circledR}$ dengan penggunaan sesuai petunjuk pabrikan. Pengobatan pencegahan lainnya adalah pemberian antiparasit umum setiap setahun sekali menggunakan agen Ivermectin $\AA$. Pemeriksaan feses dilakukan setiap enam bulan sekali untuk survei endoparasit. Suplementasi kalsium ditambahkan pada pakan. Perawatan hewan yang layak di penangkaran harus tetap dipertahankan sebagai antisipasi jika ada kasus penting dimana penangkaran adalah satu-satunya sumber individu
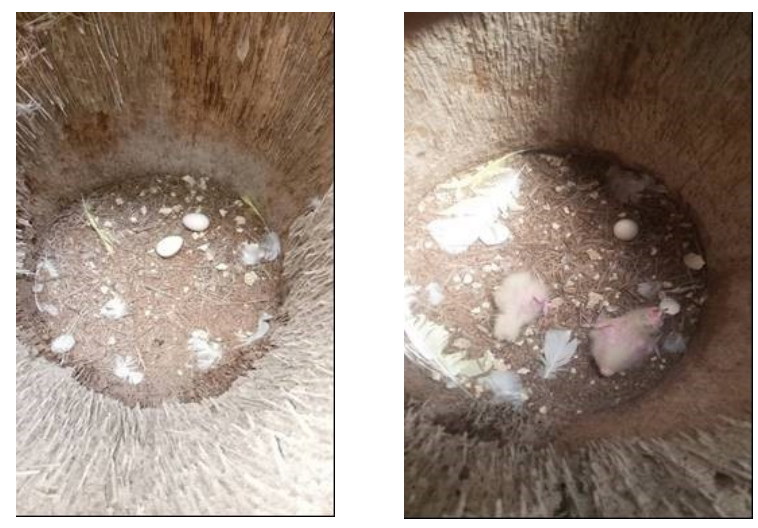

Gambar 2. Telur C. galerita di sarang (kiri) dan anakan $C$. galerita umur 1 hari dan 3 hari suatu jenis untuk reintroduksi (Beck et al. 1994; Seddon et al. 2007).

Tabel 6. Rerata data fisiologi, hematologi dan kimia darah normal pada C. galerita

\begin{tabular}{|c|c|}
\hline Parameter & Kisaran Normal \\
\hline \multicolumn{2}{|l|}{ Fisiologi } \\
\hline Suhu tubuh* & $41,2^{\circ} \mathrm{C}$ \\
\hline Pulsus jantung* & 127 denyut/menit \\
\hline $\begin{array}{l}\text { Pulsus saat } \\
\text { direstrain**** }\end{array}$ & 150-350 denyut/menit \\
\hline Laju respirasi $* * * *$ & $15-20 \mathrm{x} /$ menit \\
\hline $\begin{array}{l}\text { Laju respirasi saat } \\
\text { direstrain**** }\end{array}$ & $25-40 \mathrm{x} / \mathrm{menit}$ \\
\hline Berat badan* & 880 gram \\
\hline Dewasa kelamin* & 5-6 tahun \\
\hline Jangka hidup* & 30-45 tahun (penangkaran) \\
\hline \multicolumn{2}{|l|}{ Hematologi } \\
\hline $\mathrm{PCV}^{* *}$ & $40-50 \%$ \\
\hline Eritrosit*** & $2,4-3,0 \times 10^{6} / \mu 1$ \\
\hline Leukosit*** & $12-16 \times 10^{3} / \mu 1$ \\
\hline Hemoglobin*** & $13,8-17,1 \mathrm{~g} / \mathrm{dl}$ \\
\hline Limfosit*** & $22-56 \%$ \\
\hline Monosit*** & $0-2 \%$ \\
\hline Heterofil $* * *$ & $44-75 \%$ \\
\hline Eosinofil $* * *$ & $0-1 \%$ \\
\hline Basofil*** & $0-1 \%$ \\
\hline $\mathrm{MCV}^{* * *}$ & $145-187 \mathrm{fl}$ \\
\hline $\mathrm{MCH}^{* * *}$ & $53,8-60,6 \mathrm{pg}$ \\
\hline $\mathrm{MCHC} * * *$ & $33,3-37,6 \mathrm{~g} / \mathrm{dl}$ \\
\hline Trombosit*** & $7-24 \mathrm{~K} / \mu \mathrm{l}$ \\
\hline \multicolumn{2}{|l|}{ Kimia Darah } \\
\hline $\mathrm{AST}^{* * *}$ & $120-208 \mathrm{U} / \mathrm{L}$ \\
\hline Kalsium*** & $8-12 \mathrm{mg} / \mathrm{dl}$ \\
\hline Kolesterol*** & $146-248 \mathrm{mg} / \mathrm{dl}$ \\
\hline Glukosa*** & $200-345 \mathrm{mg} / \mathrm{dl}$ \\
\hline $\mathrm{LDH}^{* * *}$ & $118-374 \mathrm{U} / \mathrm{L}$ \\
\hline Total protein $* * *$ & $2,4-4,8 \mathrm{~g} / \mathrm{dl}$ \\
\hline Asam Urat ${ }^{* * *}$ & $2,2-1,1 \mathrm{mg} / \mathrm{dl}$ \\
\hline $\mathrm{CPK}^{* * *}$ & $144-439 \mathrm{mg} / \mathrm{dl}$ \\
\hline
\end{tabular}

*)Pollock, 2012; **)Hoppes, 2019; ***) Capitelli \& Crosta, 2013; ****) Harrison \& Ritchie, 1994 


\section{KESIMPULAN}

Volume ekspor jenis C. galerita yang paling tinggi yaitu pada tahun 1988, baik yang dilaporkan oleh importir (3960 ekor) maupun yang dilaporkan oleh eksportir (5316 ekor). Negara tujuan yang paling besar volume perdagangannya adalah ke Amerika Serikat, baik menurut laporan dari importir (6484 ekor) maupun laporan dari eksportir (7028 ekor) dengan volume tertinggi yaitu pada tahun 1988 yaitu 3.879 ekor (menurut laporan importir) atau 4.199 ekor (menurut laporan eksportir). Sebagian besar ekspor $C$. galerita yaitu dalam bentuk hidup sekitar 99,8\%. Tujuan yang dilaporan oleh importir sebesar 98,78\% adalah untuk kepentingan komersial. Sebagian besar spesimen $C$. galerita yang dikirim tidak mencantumkan kode (source code). C. galerita di fasilitas penangkaran burung Pusat Penelitian Biologi-LIPI memiliki frekuensi reproduksi 1-2 kali/tahun. Bertelur 1-2 butir/peneluran. Masa pengeraman \pm 28 hari. Berat telur $19 \pm 1,12 \mathrm{~g}$. Panjang telur 4,28 $\pm 0,08 \mathrm{~mm}$ dan lebar telur $3,35 \pm 0,05 \mathrm{~mm}$. Anakan umur 7 hari memiliki berat $95 \pm 2,34$ gram. Anakan keluar sarang pada umur \pm 11 minggu dan dapat terbang umur \pm 13 minggu. Proses bertelur jika lebih dari 1 butir tidak berlangsung pada waktu yang sama, begitupun dengan waktu penetasannya, biasanya berselang 12 hari.

\section{UCAPAN TERIMA KASIH}

Terima kasih kepada Pusat Penelitian Biologi-LIPI yang telah mendanai fasilitas penangkaran burung untuk penelitian di Bidang Zoologi, Puslit Biologi-LIPI melalui anggaran DIPA.

\section{DAFTAR PUSTAKA}

Beck, BB., LG. Rapaport., MS. Price, \& AC. Wilson. 1994. Reintroduction of captiveborn animals. In Creative conservation: interactive management of wild and captive animals: 265-284. Olney, P.J.S., Mace, GM. \& Feistner, ATC. (Eds). London: Chapman \& Hall

Capitelli, R. \& L. Crosta. 2013. Overview of psittacine blood analysis and comparative retrospective study of clinical diagnosis, hematology and blood chemistry in selected psittacine species. Veterinary Clinical Exotic Animal_.16: 71-120.

CITES. 2013. A guide to using the CITES Trade Database. United Nations Environment Programme World Conservation Monitoring Centre.

. 2017. Appendices I, II dan III. https:// cites.org/sites/default/files/eng/app/2017/ E-Appendices-2017-10-04.pdf. Diakses tanggal tanggal 2 Januari 2019.

. 2019. CITES Trade Data Dashboard. http://cites-dashboards.unep-wcmc.org/ national?id=ID. Diakses tanggal 9 Oktober 2019.

De Silva, SS. \& TTA. Anderson. 1995. Fish Nutrion in Aquaculture. Chapman \& Hall Aquaculture Series, London, 319pp.

Fakultas Kedokteran Hewan UGM. 2006. Kajian Avian Influenza di Jawa Timur, Jawa Tengah, dan Daerah Istimewa Yogyakarta. Tim Fakultas Kedokteran Hewan Universitas Gadjah Mada. Yogyakarta.

Forshaw, JM. \& WT. Cooper. 1989. Parrots of The World. Third Edition. Landsdowne edition. Australia.

Gill, F \& D. Donsker (Eds). 2018. IOC World Bird List (v8.1). doi : 10.14344/ IOC.ML.8.1

Goddard, S. 1996. Feed Management in Intensive Aquaculture. Chapman \& Hall, New York. 194 pp.

Harrison, GJ. \& BW. Ritchie. 1994. Making distinctions in the physical examination. Avian Medicine: Principles and Application. Eds. B.W. Ritchie, G.J. Harrison and L.R. Harrison. Wingers, Lake Worth.

Haryoko, T. 2018. Dinamika perdagangan ekspor burung kakatua dari Indonesia dalam kurun waktu 1981-2017. Disampaikan pada Prosiding Seminar Nasional Konservasi dan Pemanfaatan Tumbuhan dan Satwa Liar. Salak Tower Hotel, Bogor, 27 November 2018.

Hoppes, SM. 2018. Management of Pet Birds. https://www.msdvetmanual.com/exoticand-laboratory-animals/pet-birds/ management-of-pet-birds. Tanggal akses 
8 Januari 2019.

IUCN. 2019. The IUCN Red List of Threatened Species. Version 2018-2. https://www. iucnredlist.org/species/22684781/

131914971\#. Di akses tanggal 3 Januari 2019.

Keputusan Presiden No. 43 Tahun 1978 Tentang: Convention On International Trade In Endangered Species of Wild Fauna And Flora

Keputusan Menteri Kehutanan Nomor 355/Kpts -II/2003 tentang Penandaan Spesimen Tumbuhan dan Satwa Liar.

Lee, SH., JH. Choi, N. Lee, HR. Lee, JI. Kim, NK. Yu, SL. Choi, SH. Lee, H. Kim, \& BK. Kaang. 2008. Synaptic protein degradation underlies destabilization of retrieved fear memory. Science 319 (5867): 11253-1256.

Lyons, J. A., RWG. Jenkins \& DJD. Natusch. 2017. Guidance for Inspection of Captive Breeding and Ranching Facilities. CITES Secretariat. Switzerland.

Noerdjito, M. \& I. Maryanto. 2007. Jenis-Jenis Hayati yang Dilindungi PerundangUndangan Indonesia. LIPI Press. Bogor.

McLeod, A., N. Morgan, A. Parakash \& J. Hinrichs. 2007. Economics and Social Impacts of Avian Influenza. FAO, Emergency Centre for Transboundary Animal Disease Operations (ECTAD).

O'Brien, J. 2007. Husbandry Guidelines for Cacatua spp. European Breeding Program. Ireland

Peraturan Pemerintah Republik Indonesia Nomor 7 Tahun 1999 Tentang Pengawetan Jenis Tumbuhan dan Satwa

Peraturan Menteri Lingkungan Hidup Dan Kehutanan Republik Indonesia Nomor P.92/ Menlhk/Setjen/Kum.1/8/2018 Tentang Perubahan Atas Peraturan Menteri
Lingkungan Hidup Dan Kehutanan Nomor P.20/Menlhk/Setjen/ Kum.1/6/2018 Tentang Jenis Tumbuhan Dan Satwa Yang Dilindungi

Peraturan Menteri Kehutanan Nomor P.19 Tahun 2005 tentang Penangkaran Tumbuhan dan Satwa Liar.

Pollock, C. 2012. Basic Information Sheet: Cockatoo. https://lafeber.com/vet/basicinformation-sheet-for-the-cockatoo/. Tanggal akses 8 Januari 2019.

Ricklefs, RE. \& CD. Cadena. 2007. Lifespan is unrelated to investment in reproduction in populations of mammals and birds in captivity. Ecology Letter. 10, 867-872.

Rowley, I., GM. Kirwan \& P. Boesman. 2019. Sulphur-crested Cockatoo (Cacatua galerita). In: del Hoyo, J., Elliott, A., Sargatal, J., Christie, D.A. \& de Juana, E. (eds.). Handbook of the Birds of the World Alive. Lynx Edicions, Barcelona. (retrieved from https://www.hbw.com/ node/54423 on 4 January 2019).

Seddon, PJ., DP. Armstrong \& R.F. Maloney. 2007. Developing the science of reintroduction biology. Conservation Biologi. 21. 303-312.

Sukmantoro W, M. Irham, W. Novarino, F. Hasudungan, N. Kemp \& M. Muchtar. 2007. Daftar Burung Indonesia No. 2. Indonesian Ornithologist Union. Bogor

Thompsen, JB., SR. Edward., TA. Mulliken. 1992. Perception, Conservation, and Management of Wild Birds in Trade. TRAFFIC. United Kingdom

UNEP-WCMC. 2014. Checklist of CITES species. CITES Secretariat, Geneva, Switzerland and UNEP-WCMC, Cambridge, United Kingdom. Diakses tanggal 4 Maret 2020.

WHO. 2004. Avian Influenza ("Bird Flu") and the Significance of Its Transmission to Human. WHO Fact Sheet No. 227. 